International Journal of Advanced Academic Studies 2022; 4(1): 111-114

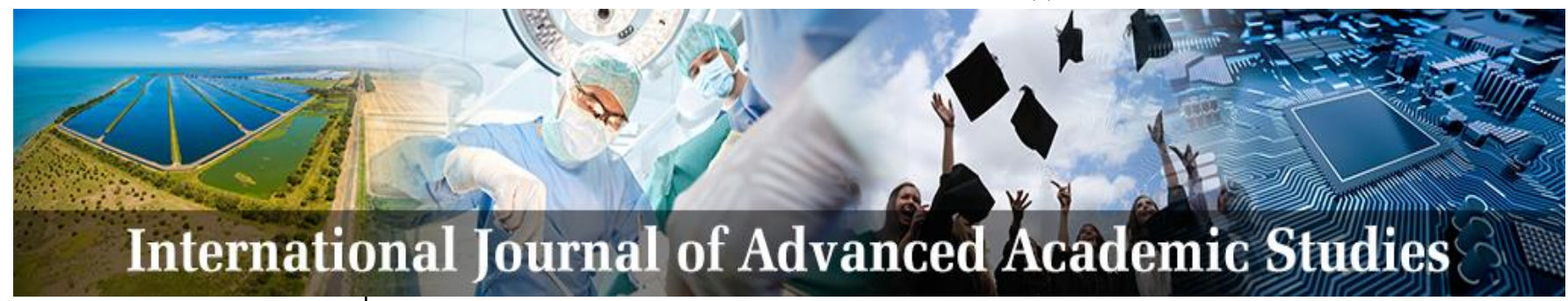

E-ISSN: 2706-8927

P-ISSN: 2706-8919

Www.allstudyjournal.com IJAAS 2022; 4(1): 111-114

Received: 17-11-2021

Accepted: 21-12-2021

Haji Mohammad Hood Assistant Lecturer, Language and Literature Faculty, Balkh University, Afghanistan
Corresponding Author: Haji Mohammad Hood Assistant Lecturer, Language and Literature Faculty, Balkh University, Afghanistan

\section{Language borrowing in Pashto}

\section{Haji Mohammad Hood}

DOI: https://doi.org/10.33545/27068919.2022.v4.i1b.693

\begin{abstract}
A language evolves when it transforms: new words are coined and some others are getting old, less used, and eventually go obsolete. Some words drop their original meaning and acquire a new one. Others keep the original meaning alongside the new one. The process doesn't occur overnight and in one location. It is rather gradual and takes time. Also, academic terms emerge in a language, either translated or borrowed, especially in natural sciences, technology, religions and social sciences. Below, I will explain how these borrowings happen, and what their types are.
\end{abstract}

Keywords: Linguistic borrowing, borrowing translation, word borrowing, phonemic borrowing, syntactic borrowing

\section{Introductions}

Language is one of those complex systems that human beings deal with over the course of their lifetime. A human can create, by their language competence, an indefinite number of sentences out of a handful of grammatical principles and a definite number of words. The same way, they can understand an indefinite number of sentences produced by other speakers of the same language. Obviously, it is the language performance that has made the language a complex system. There are particular nuances a language system has that have set it apart from other communicative systems of human beings and have made it the most valuable of all. One of these characteristics is the process of language change. It suggests that the different aspects of a language transform over the time, including phonemes, morphemes, and syntax. As evident, most of the changes occur in the morphology of a language - new words are usually coined and added to the vocabulary of a particular language. In the meantime, some of the words vanish and drop off. Today, words like jamdar, traplal, grohedal are no longer part of daily conversation, since the concepts they denoted have disappeared in the culture of Pashtuns, while words like police, cinema, restaurant, and café, for instance, have been added to its vocabulary. Therefore, the role the social and cultural factors play in the evolution of a language is undeniable. At times when a speaker of Pashto cannot find an appropriate word to express a particular concept, he or she borrows words from languages they know and fill in the gap - thus, the language borrowing occurs. When some elements, especially words, are transferred from one language to the other, it is called language borrowing.

\section{Related works}

There is plenty of research done on the language borrowing in languages I am known to, but Pashto, as my native tongue, is pretty new to the matter. The author of Pashto Historical Linguistics, Mahmud Marhoon, a professor at the University of Kabul, has slightly touched the topic and that is it. My work is largely the first step in the field of Pashto language borrowing.

Research Objective: The objective of the research is to draw the line between language borrowing and loan translation in Pashto language. The types of language borrowing will be discussed as well.

Methodology: It is an analytical research, using first hand evidence and authentic books.

Value and Conclusion of the Research: The value of the research is to introduce the language borrowing and its types in Pashto. It will answer the question of the degree of language borrowing in Pashto as well. 
In the meantime, the advantages and disadvantages of loanwords will be identified. Thus, helping the public, the students, the teachers and those involved in the media to be conscious of the terms and expressions they borrow or the ones already borrowed. The languages Pashto has borrowed many words from have been identified as well.

\section{Language Borrowing}

Borrowing in a language depends on its speakers' social history and politics. When a language borrows some ingredients from another language and incorporates them within itself is usually called language borrowing - in a way that fills the vacuum among the words of the target language. When the Russians sent the first rocket to the space, they called it sputnik which was borrowed by the western media until they found their own word: the satellite (Gandumkar. 1397. 93) ${ }^{[5]}$.

Einar Haugen, the author of Analysis of Linguistic Borrowing, says that the term borrowing requires further contemplation as he thinks it is "inept" for the process. According to him the linguistic borrowing looks like stealing since the target language does it without the "consent of lender" language and does not repay the debt either (Haugen, 1950, 211).

But, to reject Einar's idea of theft, it is worth mentioning that the source language does not feel cheated in lending words and does not lose anything by doing so.

\section{Loanwords}

Words coming or borrowed from one language to another do not influence the grammar of the target language. Words are the most unstable part of a language - some words may prevail and others may go obsolete, depending on the conditions of a particular society. When a society, for instance, borrows something from another, it is more likely that the word designating it will also be borrowed by speakers of the former. When the word gets fully absorbed, it will be subjected to the grammar of the target language. We can bring the following words as examples of loanwords borrowed from English in the fields of trade, technology: computer, internet, telephone, mobile, hello, Facebook, WhatsApp, Telegram, Messenger, charger, credit, and so on.

The Arabic loanwords are spelled in its original form but not all of them are pronounced the way an Arab does. It is due to the places of articulation a Pashto speaker is unfamiliar with and pronounces them with the close equivalents but since the script of Pashto is based on Arabic alphabet, the original spelling is kept.

This is not only true about Pashto, every small and large language of the world borrows words. Dari, the second official language of Afghanistan, has lost the count of Arabic loanwords within its vocabulary. English, the most advanced and world-wide language at the moment and widely used in science and technology, has a large number of loanwords. For example, look at the following words: bagel (Yiddish), goulash (Hungarian), enchilada (Mexican), savoir faire (French), aggiornamento (Italian) and gemütlich (German). These words were borrowed because English could not replace them with words from its own vocabulary at that point.

It is not necessary, just to clarify, that the thing/practice a loanword denotes must be accepted in the culture of the borrowing society. The only condition under which a language borrows a word from a source language is the fact that there is an interest towards a concept, or a layer of it, in the target society. For instance, the concepts of lama (an honorific title granted for a spiritual leader in Tibet) and llama (a wooly domesticated animal) did not solidify a place in English tradition but the words themselves were accepted-even those English speakers with intermediate level of education can understand them. When the first English speakers arrived in the New World, they incorporated many words regarding the culture of the new found people in their language: They couldn't even dream about the equivalents of pemmican, wampum, and wigwam in their society. Today, the English speakers talk about junta, freely, without necessarily accepting a similar state institution within their country.

Another example of incorporated loanwords could be seen in Turkey: According to Turkish phonology, words do not begin, or get pronounced, with a sequence of two constants led by an /s/ sound. The words beginning with /s/ + /consonant/, which were borrowed from some European languages, usually take an /i/ at the beginning. See below:

Table 1. List of loanwords in different languages

\begin{tabular}{|c|c|c|c|}
\hline Word & Source Language & Turkish & Meaning \\
\hline Spirito & Italian & Ispirto & Spirit/alcohol \\
\hline Station & French & Istasyon & Station \\
\hline Scotch & English & Iskoč & Scottish \\
\hline
\end{tabular}

\section{Loan Translation}

Loan translation, on a phrasal level, is a word-by-word translation. According to Andrey Fyodorov, loan translations enter a language with its referents - something we will look at suspiciously. As an example, he brings up the Russian loan translation of gromkovoritel which was a translation of loudspeaker. When the Russians were first introduced to supermarkets, they used the svierkhrynok loan translation but it led to some confusion. Thus, before coining the phrase self-service shop, they used a phrase that meant 'without assistant shop' (Gandumkar.1397. 95) ${ }^{[5]}$.

Now, as English has indiscriminately borrowed many words from other languages, it has a special place among the languages. The English speakers have no concerns regarding the loanwords either vanishing or losing the authenticity of their language. In English, an original and a loanword, with similar meanings, can coexist. Words such as handbook (English) and manual (French) exist alongside one another. It is also possible that an alien word sometimes replaces an ancient word for no obvious reason. The ancient English word astigan, for instance, was replaced by ascent (Latin: ascendere). Even if all words of an expression are authentic, yet the number, combination and the sequence of the words could be borrowed from the source language, making the expression still a loan translation.

English borrowed the word compassion from Latin through French. But Germans divided the word into two-com (with) and passio (feeling) - and have translated them separately as mit and leid and made it as mitleid (empathy) (Mudaresi 1384. 215) ${ }^{[6]}$.

In Iran, they have a standard for all of these loanwordsthey are pronounced, for instance, in the same fashion. But in Afghanistan, there is no any uniformity regarding the loanwords. We, in Afghanistan, call India as Hindustan and Georgia as Gurgistan. But we don't call Bulgaria as Bulgaristan and Mongolia as Mongolistan. One of the 
reasons is probably the lack of a center where the standards are designed and approved. The list of these confusing words is exhausting. I just bring a number of them below just to clarify things (Wahedi. 1396. 107) ${ }^{[3]}$ :

Table 2. List of confusing words

\begin{tabular}{|c|c|c|}
\hline إيوزبشن & ايوزسيون & opposition \\
\hline سوسيليزم- سوشيلزم & سوسياليسم & socialism \\
\hline كمونبزم & كمونيسم & communism \\
\hline رياليزم & رياليسم & realism \\
\hline رومانتيزم & رومانتيسم & romanticism \\
\hline كييتليزم & كايِيتاليسم & capitalism \\
\hline انتزرنشنليزم & انترناسيوناليسم & internationalism \\
\hline هيموكر ات & دموكر ات & democrat \\
\hline يوريّ & اروبا & Europe \\
\hline
\end{tabular}

When Alexander Graham Bell invented an electronic device to carry human voice to distances in 19th century, the word telephone was created from the combination of two Latin words - tele (distance) and phone (voice) — many languages, including French and Russians, borrowed the word but German preferred to go with loan translation. Thus, the word Fernsprecher, with fern (distance) and sprecher (speaker), was created.

When the western culture of relationships made its way into Chinese and Japanese societies, the words boyfriend and girlfriend came with it. While the Japanese borrowed the word, with some slight changes, as bōifurendo and gārufurendo, the Chinese, who are somewhat conservative compared to the Japanese, preferred loan translation: nan pengyu $($ nan $=$ male + pengyu $=$ friend $)$ and nü pengyu $(n \ddot{u}$ $=$ male + pengyu $=$ friend). Pashto doesn't only come short of academic researches but it also has a lower number of vocabulary. There are thousands of words in English and in other advanced languages that we do not have equivalents of in Pashto, particularly in the field of new technology and sciences. We have similar loan translations in Pashto. Look at the following examples:

Table 3. List of similar loan translations in different Language

\begin{tabular}{|c|c|c|}
\hline Pashto & Dari & English \\
\hline Wrazpana (ورحُبانه) & roznama (روزنامه) & newspaper \\
\hline Par makh tag (يְرمختى) & peshraft (يبشرفت) & development \\
\hline Khatiz Pezhandana (ختيخ يبزْزندنه) & Sharq Shenasi (شرق شناسى) & orientalism \\
\hline Bawarlik (باورليك) & etemadnama (اعتمادنامه) & trust letter \\
\hline \multicolumn{3}{|c|}{ In verbs too } \\
\hline Manz ta ratlal (منح ته ر اتلل) & ba mian amadan (به ميان آمدن) & to take place \\
\hline La manza tlal (له منـَّه تلل) & az bain raftan (از بين رفتن) & to destroy \\
\hline Tar lasa kawal (تر لاسه كول & ba dest awardan (به دست آوردن) & to achieve \\
\hline La lasa warkawal (له لاسه وركول) & az dast dadan (از دست دادن) & to lose \\
\hline
\end{tabular}

And similarly, some of the of translators fall under the impression of the source languages and publicize weird and sometimes inaccurate terms in Pashto (Afghan likwal.1396. 94).

\section{Loan Phoneme}

We know a lot about the loanwords, and we made it clear that it is totally possible to borrow a word or words from other languages. But a phoneme or a group of phonemes do not transfer from one language to another, at least easily. When a word is absorbed in the target language, it might lose all the characteristics it had in the source language. When $/ \mathrm{k} /$ is followed by an $/ \mathrm{n} /$, for instance, the $/ \mathrm{k} /$ dropsknife, know, knee are pronounced as [ni:], [no:], [nayf]but the letter $\mathrm{k}$ is still kept in the written form. Or, English has no /ž/ and any word containing this sound is actually borrowed from French usually during the 1066-1250 invasion. You can hear the sound /ž/ in rouge [ru:ž].

If a language has a social, official and political dominance in a multilingual country where it serves as a lingua franca and the primary language of the schools, universities, and other academic centers, many words of that language will make their way into the languages of minorities. Russian, for instance, is one of these-many of its words have entered the languages used in the former Soviet Union. There is no /f/ sound in Kazakh, for instance. Yet, the Russian loanwords containing /f/ sound is perfectly pronounced by Kazakhs who can speak the Russian as well. See the following examples:

Flot (ship), filosof (philosopher), fizika (physics) were pronounced with a /p/ sound, instead of /f/, well before they learned a great deal of Russian. In other words, they replaced /f/ with a /p/ around forty years ago.

We have ten loan phonemes in Pashto- ث، ح، ذ، ص، ض، ط، - which are still pronounced incorrectly, particularly by those who do not have a great degree of education or none. س س س they are articulated in the same place - all of the three can be represented by phoneme /s/. ذ ذ، ظand $j$ have the same problem and can be represented by phoneme /z/. The phoneme /f/, or $\boldsymbol{i}$ in Arabic letters, is usually articulated as $/ \mathrm{p} /$, the $\mathrm{b}$ is pronounced as $ت$, or simply /t/ phoneme, the $\tau$ is pronounced as $\rightarrow$, or $/ \mathrm{h} /$, the $\varepsilon$ is sometimes articulated as !, or $/ \mathrm{a} /$, and is usually turned into $s$, or $/ \mathrm{k} /$. This shows that these loan phonemes had made it to Pashto from Arabic through loanwords. Though there is no any issue in writing them up, their articulation is not authentic.

\section{Syntactical Borrowing}

When a syntactical structure goes from one language to another, due to their linguistic relation, it is called syntactical borrowing. In Persian, for instance, the expression chera na/chera ke na (Persian: جر انه/جر ا كه نه) is a loan translation coming either from French 'pourquoi pas' or from English 'why not'. (Naghzgoy kohan.1393 .362)

Syntactic borrowing is probably more unusual than the phonetic borrowing. In English, some of the syntactic borrowing can be found in the law terms. Attorney general and court martial, for instance, are combined according French syntax: The name is followed by the adjective. In normal situation, the adjective is followed by a name. Though some other terms are created using the pattern 
above - such as the postmaster general — but these kind of phrases are largely kept peripheral.

Another good example of syntactic loans is the Persian additive phrases that have made it to Turkish. In Persian, the modifier follows the noun. All they do is add /e/ sound at the end of the first noun. See the following example: Adame-Bahush (smart man). In Turkish, this is opposite. The modifier is followed by the modified noun: Akil adam (smart man). But some of the Persian phrases that have entered Turkish during the Ottoman Empire have changed the /e/ into /i/ sound. See the following example:

Donanma - i - hümayun (royal warship)

Also, in a morphologic change, Arabic nunation and some Arabic and English suffixes have made it to Pashto and Dari.

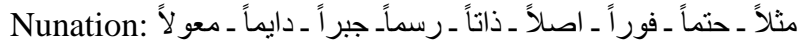

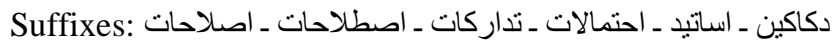

English suffix of ess is used for female doctors (i.e. doctoress) in Dari, especially on sings and boards.

Also, the influence of Arabic and Dari syntax in Pashto's old texts is visible. We can see syntactic borrowings of the two aforementioned languages in Pir Roshan and Khushal Khattak's works. See the example below:

Khushal Khan Khattak has brought a hadith in his book Dastarnama, where he writes about modesty, and has translated as following:حيا يوست د ايمان دى. The word بوست is the word modified and should have come after ايمان دان دان modifier, to make it fully Pashto. Now, the phrase is formed on Dari syntax. It should have been like this: حيا د ايمان يوست (Khattak.1345 . 96-99). Another example is the following sentence, also Khattak's: ملوكان سايه د خداى د لطف دي

\section{Conclusion}

The language borrowing and loan translation is a natural process among languages and play a role in their expansion and enrichment. However, it affects the purity and authenticity of languages in question and creates troubles in their phonological systems. Their pros are more than their cons. As a result of the research, I conclude that no word to be borrowed from another language unless necessary because the loanword can break the rules of grammar and the people with less education will have difficulties knowing it. If we want to purify and help with the enrichment of our language, we should use words consciously and try to speak and write as friendly and easy as possible so that it should not become a headache and a tiring task for people who reads. If we ignore this simple fact, all our write ups will lose its validity. Working in the field of loan translations, we need to know about the language borrowing thoroughly and understand its types. We should avoid excess borrowing in order to keep our language from facing troubles. The loan translations and borrowings that impact Pashto's authenticity are more harm than advantage. These harms are grave, serious, and mustavoided because if the borrowing continues at the current pace, Pashto will become alien, artificial, and unnatural.

\section{References}

1. Zyar, Mujawer Ahmad. Pashto Grammar. 3rd Edition. Kabul: Danish Printing Association. 1384.

2. Khweshkai, Mohammad Sabir. Pashto Phonology and Morphology. Nangarhar: Momand Printing Association. 1394.
3. Wahidi Asadullah. Effects of Translation on Pashto Prose. Kabul: Acsus Bookstore. 1396.

4. The Specialists of Translation and Prominent Writers of the Country. Guide of Academic Translation. Kabul: Afghan Writers. 1396.

5. Fawcett Peter. Translation and Language - Linguistic Theories Explained. Translated by Rahela Gandumkar. Tehran: Maharat. 1397.

6. Arlotto Anthony. An Introduction to Historical Linguistics. Translated by Yahya Mudaresi. Tehran: Farshewa Print. 1384.

7. Khattak Khushal. Dastarnama. Kabul: Pashto Association. 1345.

8. Meherdad Naghzgoy. Descriptive Dictionary of Historical Linguistics. Tehran: Ramin. 1393. 